\title{
Research Activities of Students and Information Technology as a Method to Support Interdisciplinary Teaching in Training Process of Technical University
}

\author{
M.V. Grigoryeva, T.S. Kust \\ Yurga Institute of Technology \\ TPU Affiliate \\ Yurga, Russia
}

\author{
M.V. Grigoryeva, E.B. Gribanova \\ Tomsk State University of Control Systems and \\ Radioelectronics \\ Tomsk, Russia
}

\begin{abstract}
The paper is focused on research activities of students seen as a method to implement interdisciplinary teaching in training process at a technical University, to develop professional competences of present-day graduates via group training. Outcomes of practical use of this approach are shown as activities of a students' creative team, working in the field of multi-level business with the use of information technology.
\end{abstract}

Key words: research activities of students, group training, interdisciplinary teaching, multi-level marketing, mathematical simulation.

\section{INTRODUCTION}

The contemporary system of higher education is not aimed at training well-qualified experts with perfect professional knowledge only in the period of evolving information-oriented society. State Program "Information-oriented society ( for years 2011 to 2020)", ratified by the Government of the Russian Federation in 2014 set special requirements for graduates of technical Universities. Higher education is to develop professional competences of University students. The need for polymaths, who are able to assess situations objectively and make creative and unconventional decisions, has become more pronounced due quickly changing conditions in all spheres of our life. A lot of present-day authors address the issue in their papers [1 - 5].

A modern system of University training has a wide range of didactic tools, which are directed mostly at teaching students only one subject without making knowledge of various disciplines interconnected. As the result, a graduate often has an uncoordinated sum of knowledge, abilities and skills. It is the basic problem of training Bachelors and Masters in the field of Engineering, in particular, Information Technologies.

\section{Methods OR RESEARCh, CONCEPTS AND DeFINITIONS}

Before New Generation Federal State Educational Standards had been introduced, a professional was supposed to meet requirements of the job and have particular knowledge specified by the field, as the consequence, training students was concentrated on providing them with standardized information, abilities and skills.
However, it is claimed in Federal State Educational Standards that a graduate should acquire both general knowledge and be aware of a particular wide speciality. He/she should have a well-developed ability and willingness to use personal skills successfully and improve quality and efficiency of his/her activities.

The concept of comprehensive training, forming and developing contemporary personality, supporting his/her ability to be an expert with fundamental knowledge in the filed and a member of a staff or society as well, is based on a competenceoriented approach, which consolidates professional competence and training content.

What does the concept "competence" mean?

Competence implies mastering skills, meeting specified standards of training, necessary for efficient professional activity. Competence can be also considered as a set of characteristics a student has, which make him/her prepared for carrying out various professional activities.

Professional competence of technical students can be defined as developed and consolidated personal characteristics, which will support successful practical application of knowledge, abilities and skills in their prospective work in the field of engineering.

Competence-oriented approach necessitates a serious change in training technologies. Therefore, nowadays the Universities are responding to the challenge of developing special technologies and procedures of their implementation in the training process.

Professional competence development of a prospective technical expert can hardly be possible without context-based training and relying on interdisciplinary teaching. Contextbased training involves modeling professional and social components of a prospective engineering activity, and interdisciplinary teaching consolidates knowledge of various fields of science.

Interdisciplinary teaching is a process of combining academic disciplines, demonstrating persistent and integral character of professional activity. It is worth emphasizing, interdisciplinary connection of some academic disciplines in a curriculum can't be the only aim; it is important to comply it 
with integral approach, providing the base for implementation of interdisciplinary teaching in the entire training process.

Interdisciplinary integration is thought as a supreme form of consolidated aims, principles and content of training, developing large-scaled connection of all academic disciplines in the curriculum.

Research carried out in the process of training is oriented at augmentation of general theoretical knowledge, scientific achievements, which can lay down the foundations of innovative manufacturing technologies.

Professional competence of students is to be developed from their first year at the Universities. At a technical University students can be engaged in academic research due to prevailing interdisciplinary connections. It is very efficient to form groups of students majoring in various fields for cooperative research. In this case students will master their profession, develop their communicative skills, as well as perfect team working.

\section{RESEARCH WorK OF StUdents VIA GROUP PROJECT- BASED LEARNING}

The aim of Tomsk Polytechnic University and Yurga Institute of Technology is to support and promote innovative activity of students, who are trained these days, to run their own science intensive business and initiate and implement innovative projects at any real enterprise. For this purpose research activity of students is organized, alongside with it group project-based learning has been recently evolved, while students are divided into small creative groups.

The subject domain of a project can be chosen via searching for ideas and proposals and selecting the most competitive ones. Everybody can take part in the competition: lecturers, University engineers, and students, making their proposals, as well as companies, enterprises and firms interested in development and manufacturing new science intensive products. Basic requirements a project is to meet include novelty and science intensive character of a project, as well as outlooks of promoting a product at the market.

Students interested in group project-based learning are divided into creative teams consisting of 5 to 7 persons. There is a manager in each project, whose responsibility is focused on directing activity of a group, selecting the subject domain of a project, planning stages and terms of project implementation. Each individual in the group has a special task answering the project domain.

Students of various years, majoring in different fields, as well as representatives of different departments and faculties, even students of other Universities are involved in a project due to up-to-date well-developed communication means. The entire learning trajectory of a student, involved in group project-based learning, will be concentrated on the project domain from his/her enrollment into the University and to graduation from it. All year essays are to be in line with subjects relative to group project-based learning. This requirement is relevant for laboratory work, too. As the consequence, a student, working on his/her graduate paper will be a confident expert in the subject; he/she dealt with during several years.
Being a constituent part of training specialists, bachelors, masters, group project-based learning, focused on an actual project, furthers theoretical knowledge consolidation and improvement of practical skills necessary for project, research, as well as organization and control activities. Students, working together at the same project, become confident in setting relevant goals, revealing and discussing possibilities of its implementation. Students, involved in group project-based learning, suppose the process of their training is more creative, informative, fascinating, therefore, more efficient [4].

As an example of such training we address to activities of project group called "Model of multi-level marketing". The group consisted of bachelors of Yurga Institute of Technology, TPU Affiliate, majoring in "Applied Informatics in Economy", as well as students of Tomsk State University of Control Systems and Radioelectronics, doing such courses as "Applied Informatics in Economy", "Applied Mathematics".

Over two years students, engaged in group learning, obtained a lot of experience in team working on a project, consolidated theoretical knowledge and practical skills in the following disciplines, which are not in the curriculum of their training field:

- $\quad$ project management;

- network economics;

- programming;

- imitative simulation;

- computer simulation;

- mathematical simulation;

- $\quad$ numerical methods;

- $\quad$ statistics;

- econometrics;

- foreign language;

- $\quad$ sociology etc.

The work of students on the project was divided into several phases.

Phase 1. Study on the subject domain. Students were given a task to find as much information on multi-level marketing as they could, considered an innovative technology of the $21^{\text {st }}$ century's economy. Group project-based learning participants learnt statistic data on development of multi-level business these days, read Russian and foreign literature on multi-level marketing [6-10], information presented on the official website of the Russian Association of Direct Sales. They found out in the course of their research, what challenges a distributor is to respond to, how to create a stable MLM-network, improve efficiency of direct sales and motivate agents.

Phase 2 preceded the main work and was directed at study of research procedures in present day conditions of information-based society and analysis of available models to assess profitability of a multi-level business [11, 12].

Phase 3. Brainstorming of the third phase resulted in a hypothesis: dissemination of multi-level marketing can be 
characterized by a mathematical model; further suggestions of its efficiency are possible to be made relying on the analysis of this model.

Therefore, a task was given to characterize mathematical models of a network company and region, where a MLMnetwork is to be built. These models are to be used for revealing efficiency of a company in the region, where a MLM-business is to be introduced.

Let us consider theoretical, practical and academic information students had to study within this project.

\section{A. Multi-level technologies in economy}

Present-day economy is based on network technologies being the main innovation on micro and macro scales. Innovations are becoming increasingly important for stable economic development of small and big businesses. Companies have to meet strong requirements of consumers, leave behind other companies competing on internal and international markets, and improve labor efficiency.

Human desire to be more independent on particular circumstances of the world is becoming more pronounced, this trend has already a technological foundation in form of network information technologies and achievements in new economy.

New communication technologies make it possible to get equally connected with everybody without local and time restrictions, as the result, Internet-based network business leads to radical changes in social and economic sphere.

Widely applied Internet technologies offer new economic outlooks. These days we are witnesses of gradual transition of economic relations into electronic form, distinguished by rapid developments. Network nature of the structure, low cost price and high speed make this form of economic relations undoubtedly advantageous.

Internet-based technologies have one more special feature, which can be also considered the basic one: a person is almost absolutely free to affect intangible assets and even issue own money. This fact emphasizes, that a person has the same importance as a company, sometimes even exceeding it many fold. As the result, there are no differences of a person from a corporation; a particular person gets responsible for entrepreneurial activity. Meanwhile, instruments of work organization become so powerful that currently incredible production can be developed on their base. Some examples are already available.

Internet-based technologies are advantageous in business because producers and consumers have equal possibilities to get directly connected without middlemen. Therefore, network form of economic activities sets special requirements for all key participants of market relations.

\section{B. Direct Sales and Multi-Level Marketing}

The terms "direct sales" and "multi-level marketing" are often thought to be synonyms, however, experts have the opposite opinion. The Association of Direct Sales adheres to the following official position, how these terms can be used.
Direct sale is a kind of distribution, a type of retail trade out of a stationary retail network. Goods are sold to the end consumer via their presentation by an individual or group.

Multi-Level Marketing is a concept of selling goods and services based on a network of independent market agents (network agents, distributors), each of them alongside with selling goods can also invite partners, having the same rights. Here, income of each network agent includes commission obtained for selling goods and additional compensation (bonus), depending on the volume of sales, made by their invited agents and consumers. Multi-level marketing is a form of off-shop retail trade, a special kind of direct (personal) sales, distinguished by contacts with potential consumers, established independently by market agents of companies, manufacturing goods.

Entrepreneur activity of a distributor is to be professional in and out of the field of sales. Multi-level marketing, considered as an outlook of developing a huge network of consumers and distributors, highlights the importance of informative academic activity for this technology of goods promotion, which consists of the following components:

- distribution of information on goods and services;

- distribution of information on business possibilities;

- training distributors in the field of information distribution;

- training distributors in the field of multi-level marketing entrepreneur activity.

MLM-business is run in almost all countries of the world. The number of companies in this market segment is over 5000 . MLM-industry is a world leader of quickly developing economic systems. More 74 million people are employed in MLM-industry at present. MLM-business has been one of the most intensively developing activities in the world over the last 10 years, annual increase of the world goods turnover of this industry is $20 \%$ to $30 \%$. Its rates of growth are in line with those of telecommunications, software and pharmaceutics [5]. Every day 50 and more people all over the world become millionaires of multi-level marketing. $50 \%$ all goods and services in the USA and $90 \%$ in Japan are sold via MLM [6].

In 2005 it was claimed by Federation Council of the Russian Federation at Petersburg International Economic Forum that network technologies are a foundation of global economy of Russia in the $21^{\text {st }}$ century [15]. Representatives of multi-level business appeared first in Russia 22 years ago; more 700 companies are currently working in our country. Nearly 7 million distributors are employed in these companies; 25 million people are regular customers of products offered by MLM-companies. The number of employed distributors in Russia is 5 million people (the $1^{\text {st }}$ position in Europe), the turnover of multi-level companies registered in Russia amounts to $\$ 3.1$ milliard, added value tax is not taken into account (the $3 \mathrm{~d}$ position in Europe) [5].

Multi-level marketing in Russia is not only a special way of goods and services promotion. This business became a social and economic phenomenon in our country. It is the main income source for a lot of people. 
How to sort out this diversity of offers? What company should we entrust with our future? Students' research is to answer these questions of a person, making a decision to enter a MLM-business with the purpose to obtain additional income, which often gets the main one.

\section{Regression model to assess income of a network agent}

The purpose of this phase was to develop a model for assessing income of a network agent and study how factors $(x)$ affect the resultant $y$.

Carrying out research students used methods of statistics and econometrics.

Three groups of factors were identified which are relevant for agent's income: the first group characterizes agent's surroundings, the second one is focused on the company where he/she is employed and the third group is concentrated on the agent $\mathrm{him} /$ herself. Therefore, the following three groups of factors were considered as exogenous variables.

Group 1:

- $\quad$ population size in the place of residence (city);

- average incomes of population in the place of residence (city);

- number of company offices in the city.

It is not as easy as it can seem to get timely information on the surroundings where business is to be introduced. Special instruments are required as multi-level business has no boundaries, in fact, and being run correctly can be evolved into inter-regional or international business. To obtain timely information on the city where a MLM-network is planned API reference manual 2GIS was used, providing data on 277 cities and 9275 human settlements in Russia, Ukraine, Kazakhstan, as well information of portal Rosstat.

\section{Group 2:}

- turnover;

- rating;

- range of goods.

Group 3:

- $\quad$ spent time (hours a day);

- $\quad$ volume of sales (rubles a month);

- number of invitations a day;

- invitation of friends;

- MLM working experience;

- participation in company training courses;

- age.

To collect information for Group 3 of factors students suggested an empirical approach -distributers of various companies filled in a questionnaire in social networks or faceto-face. A questionnaire which network agent filled in is shown in Figure 1. Distributors from 5 Russian regions (Moscow,
Tomsk, Novosibirsk, Kemerovo and Krasnoyarsk regions) and some people from other countries were respondents in the poll. The sample includes distributors of three top network companies on the Russian market (Amway, Oriflame, Avon), monthly income of questioned MLM distributors was 2,000 to 1,500000 rubles.

We decided to use a linear additive model for income estimation:

$$
y_{i}=\theta_{0}+\sum \theta_{\rho} x^{(\rho)}{ }_{l}+\varepsilon_{l}
$$

where $\rho=1 . . \kappa-$ number of explanatory variables;

$i=1 . . n$ - number of observations;

$y$ - endogenous variable;

$x^{(\rho)}$ - exogenous variables;

$\varepsilon$-random remainder.

Various variants of the model were studied. For instance, Figure 1 shows the fragment of reference sample for the case of income dependence on seven factors.

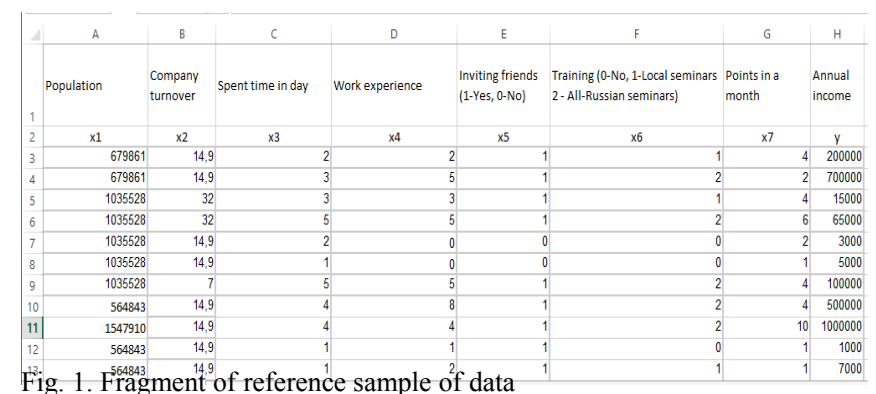

After unknown parameters had been determined by the method of minimal squares we obtained the model below:

$$
\begin{gathered}
y=-196617+0,669 x_{1}-11934 x_{2}-271780 x_{3}+175432 x_{4}-44517 x_{5}+ \\
551045 x_{6}+62117 x_{7} .
\end{gathered}
$$

The index of determination was 0.8 . Then, increase in the sample of reference data is suggested to get more precise estimation.

When implementing the project, $\mathrm{C \#} \mathrm{-} \mathrm{based} \mathrm{software} \mathrm{was}$ developed, and API 2GIS was used to obtain timely information on the city, it also made it possible to compute expected agent's income automatically under set values of input parameters. The software interface is shown in Figure 2. 


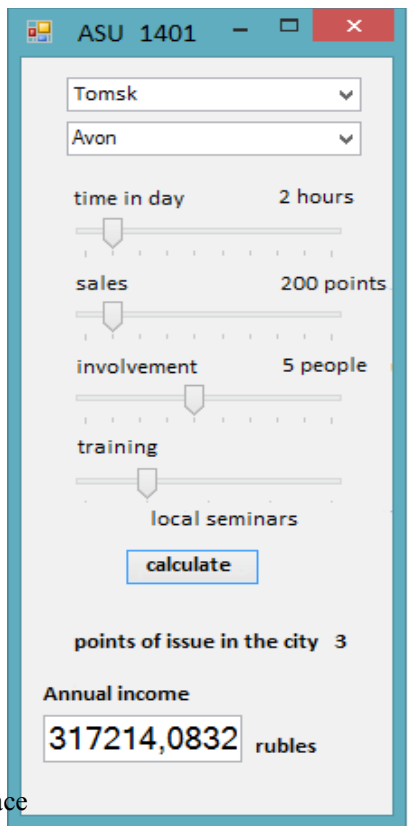

It is planned to use obtained results for developing a multiagent simulation system to model evolvement of a distribution network in the city. Alongside with the factors, listed above, motivation of agents will be taken into account in this system, which will rise together with growing incomes and contacts with other people. This work will also rely on available results of research, in particular, simulation models of distributing information in social networks.

It was assumed, mechanism of multi-level distribution was similar to dissemination of a virus disease [16]. There are a lot of models of virus dissemination, however, model SIR ( $\mathrm{S}$ sensitive, uninfected; I - infected, R - recovered, having immunity) can be applicable for the purpose of the project. This model is used to simulate epidemics of infectious diseases. In modern scientific papers some attempts were made to apply it for simulating multi-level marketing since all concepts of epidemiology can be unchangeably transferred into multi-level marketing.

This model is in line with the following system of differential equations.

$$
\begin{gathered}
d S / d t=-\beta S I \\
d I / d t=\beta S I-\gamma I \\
d R / d t=\gamma I \\
N=S(t)+I(t)+R(t)
\end{gathered}
$$

where $S$ - number of people sensitive to the disease (potential consumers);

$$
I \text { - number of infected people (current consumers); }
$$

$R$ - number of the recovered (former consumers with negative experience);

$\gamma$ - frequency of recovery;

$\beta$ - frequency of infection;

$N$ - total population size.

However, use of this model has some drawbacks in multilevel marketing. First, motivation typical for multi-level marketing as opposed to infection diseases is not taken into account in his model. It is interesting, useful and efficient to "feel" sick correctly in multi-level marketing. The second drawback is caused by the concept "income" in multi-level business, as the consequence, a "sick" person is interested in making another one infected, too. The more people a distributor makes infected, the lower is probability he/she gives up this business. As the result, the system of multi-level marketing is more stable than the virus one. It is the sphere where further research is planned to be carried out.

\section{Results of Group Project-Based Learning}

Project group activity resulted in development of software based on programming language $\mathrm{C \#}$ and.net Framework 4.5 on Visual Studio 2013. The first software can be used to analyze questionnaires filled in by distributors and calculate coefficients of the regressive model. Obtained coefficients are used in the second software to assess whether it is possible to set up a multi-level business in a particular region. This model was tested by the company of Amway in Sovietskiy district of Tomsk. It is planned to combine both software, as well as to study whether simulation, regressive and SIR-models can be used for research into network marketing.

\section{CONCLUSIONS}

The project described above demonstrates that group learning is efficient for research organization of students. Information technology as a tool technology of the educational process, provide overall support this. Students have the opportunity to plasticize in professional communication, team working, as well as they can systematize information obtained in the process of training and develop skills on the level of interdisciplinary connections and various training programs.

Therefore, interdisciplinary integration in research activity of students via group project-based learning is very important for improvement of academic and practical training. Development of professional competences is the foundation for solution of complex problems, University graduates can face in real life. Universal, creative and self-developing personality of a future expert can be formed provided that training process is continuous; all its phases are based on the same principles and methods and have the final aim - professional competence of a graduate. That is why interdisciplinary integration is considered an important condition of training and educating technical students.

\section{REFERENCES}

[1] Kochetkov G. B. World practice of science organization (on the example of the USA) // Problems of forecasting, №6, 2006, pp. 145-161. 
[2] Petrenko A.K., Petrenko O. L., Kulyamin V.V. Importance of scientific organizations in training IT experts // Proceedings of Institute for System Programming of the Russian Academy of Sciences, vol.15, 2008, pp.41-49.

[3] Kulyamin V.V., V.A. Omelchenko, O. L. Petrenko. Development of professional competences of contemporary software engineer // Proceedings of Institute for System Programming of the Russian Academy of Sciences, vol. 9, 2006, pp. 237-250.

[4] Larionov V. V., Lider A. M., Lisichko E. V. Continuous training based on project-oriented learning // Higher education in Russia. - 2011 - №. 4. - pp. 46-51

[5] Gutor S. S. , Stromov G. G. , Shilov B. V. Project-oriented learning in training specialists for development of health care information systems: student's view // Doctor and Information Technologies. - 2011 - №. 3 pp. 58-61.

[6] Anne T. Coughlan, Kent Grayson. Network marketing organizations: Compensation plans, retail network growth, and profitability//International Journal of Research in Marketing, Volume 15, Issue 5, December 1998, Pages 401-426.

[7] Dawn Iacobucci, Interactive marketing and the meganet: Networks of networks // Journal of Interactive Marketing, Volume 12, Issue 1, 1998, Pages 5-16.
[8] Strebkov D.O., Innovative potential of new economy agents // Foresight, vol. 4 №2, 2010, pp. 26-33.

[9] Miles Yen Service innovations in the $21^{\text {st }}$ century // Foresight. 2011. №2. pp.4-15.

[10] Grigoryeva M.V. Network technologies in the direct sales and their automation //Proceedings of Tomsk State University of Control Systems and Radioelectronics / 2011, № 1 (23), pp. 131-135.

[11] Popper R., Monitoring of future research // Foresight, №2, vol. 6, 2012 pp. 56-75.

[12] S.A. Balashova, O.A. Zueva. Assessment of regional factors influencing on dissemination of marketing networks in the Russian Federation // Applied econometrics, №4 (24), 2011, pp. 71-84.

[13] A. Better, Mathematical Model of Viral Marketing / Valerie Coffman. 2013. - [Electronic resource] - URL: http://www.datacommunitydc.org/blog/2013/01/better-science-of-viralmarketing-part-2, free (Access date: 9.12.2015).

[14] Tseplit A. P. , Grigorjeva A. A. , Skripkina T. A. The Models of Supporting the Strategic Decisions on Engineering Products Competitiveness // Applied Mechanics and Materials. - 2015 - Vol. 770. - p. 656-661. 